\title{
The Combination of Peer and Self-directed Feedback on Writing Achievement of Low Proficiency EFL Students
}

\author{
Rizky Amelia, Asmi Rusmanayanti \\ English Department, Faculty of Teacher Training and Education \\ Universitas Lambung Mangkurat \\ Banjarmasin, Indonesia \\ melsmasix@gmail.com
}

\begin{abstract}
Teacher feedback is a common way of giving feedback to students. However, there are gaps found particularly whether English proficiency level influences feedback effectiveness and whether feedback gives benefits students on all writing aspects. Therefore, this study examined three-fold foci whether low proficiency EFL students who were taught using the combination of peer and self-directed feedback (PSF) had better writing achievement than students who were taught using teacher feedback, whether these students benefited on content and organization aspects, and whether they benefited on vocabulary, grammar, and mechanics aspects. Employing a quasiexperimental research, this study involved two groups of 29 students given a writing test. The students were the sixth semester students who took Writing IV course at STKIP PGRI Banjarmasin. The data were analyzed using One-way ANOVA and Mann-Whitney test. The results showed that low proficiency EFL students who were taught using the combination of PSF had better writing achievement than low proficiency EFL students who were taught using teacher feedback (p-value .018). However, these students did not benefit on content and organization aspects ( $p$-value 0.243 ). They benefited more on vocabulary, grammar, and mechanics aspects (p-value 0.009). Therefore, teachers are suggested to provide their own feedback on content and organization and that the combination of PSF is used to assist them in teaching the low proficiency EFL students to reduce the burden. Further investigation involving moderate and high proficiency levels is suggested.
\end{abstract}

Keywords-peer and self-directed feeedback; writing achievement; low proficiency

\section{INTRODUCTION}

Teacher feedback is a common way of giving feedback to students. It continues to take part as a central role [12]. Nevertheless, it is not a simple task even to teachers themselves. Teacher feedback is burdensome for teachers. Most teachers spend much more time to correct students' work while the students solely spend a short time to look at the corrections [17]. It is also not impossible that the students find it hard on what to revise and how to respond to the feedback [7]. As a result, experts still continue to question the effectiveness of teacher feedback [19] [12].
An alternative to teacher feedback, namely the combination of peer and self-directed feedback (PSF), is offered in this study from an underlying condition that writing and learning are social processes and that in a real life it is common to work in pair and alone. This work creates an authentic social context for interaction and learning as collaborative peer work makes the students engage in a community and lead them to finally work individually [12]. Peer feedback is believed to be able to enhance a sense of audience [25], provides instant feedback with variety of suggestions [17], and prepares the students to work with their work later on by learning from others' strengths and weaknesses [17][19]. The peer feedback in this study is followed by self-directed feedback. Self-directed feedback is the feedback that the students found after they have revised the feedback from their friends.

Previous quasi-experimental study as in [5] showed that the students who got peer feedback and those who were exposed to self correction had better writing ability than those who exposed to the conventional editing process of writing. Nevertheless, reference [15] investigated the use of peer feedback pointed out that it was insignificantly different from the students given teacher feedback. The other study as in [9] found that self-directed feedback method showed to be significantly more effective than teacher-correction method and personality type had no significant effect on learners' progress in writing. The last previous study as in [24] showed that the peer and self revision in writing is different in quality. It was found that peer revision could be implemented for the improvement on content aspect while self revision is for language form.

Reference [24] brought some insight that there are possibilities in which students benefit on all or certain writing aspects only. Reference [23], for instance, pointed out that feedback gives significant results on all writing aspects namely content, organization, vocabulary, grammar, and mechanics. On the other hand, reference [6] found out that teacher feedback helps students in content and organization while Rahimi in [1] and [30] showed that peer feedback helps students in content and organization. These results remain in 
some doubt. Therefore, one factor in feedback effectiveness name English proficiency level is taken into account [12], [8]. Reference [11] and [18] showed that high proficiency students prefer to revise independently and were able to provide more details in explaining identified problems and offering suggestions for revisions. To fill the abovementioned gaps, this study considers the influence of English proficiency levels particularly those who have low English proficiency level and all the writing aspects to answer the following research questions:

"Do students with low English proficiency level who are taught by using the combination of peer and self-directed feedback (PSF) have better writing achievement than those who are taught by using teacher feedback (TF)?"

"Do students with low English proficiency level who are taught by using the combination of PSF have better writing achievement on content and organization aspects than those who are taught by using TF?"

"Do students with low English proficiency level who are taught by using the combination of PSF have better writing achievement on vocabulary, grammar, and mechanics aspects than those who are taught by using TF?"

\section{METHOD}

A quasi-experimental design was employed in this study to investigate the effect of the combination of peer and selfdirected feedback on writing achievement of low proficiency EFL students. There were two variables. The independent variable was feedback having two variances namely teacher feedback and the combination of PSF and the dependent variable was the writing achievement. 29 students of English Department STKIP PGRI Banjarmasin who took Writing IV course involved in this study. They were grouped into an experimental group and a control group. Post-test only was used in this study. To ensure that these groups were equal in terms of knowledge and skill, pre-test was given to students. It was found that the $p$-value was .06 was higher than .05 . As a result, the students in these two groups were homogeneous. They were labeled as Class A and Class B. Then, these classes were randomly chosen to be the control and the experimental groups by a cluster random sampling using a lottery coin for nine times. Class A was as the control group while Class B was as the experimental group. In regard to classify the students' proficiency levels, TOEFL-like test was held. 16 students were taken from the control group which consisted of 31 students. Meanwhile, 13 students came from the experimental group that consisted of 26 students. The students from high English proficiency level were not included since the focus was only on the low proficiency EFL students.

During the experimental study, each group was taught using the same materials and the same process writing approach, but they got different types of feedback. The overall ten meetings were done in which one meeting was for the TOEFL-like test, one meeting was for pre-test, one meeting for the feedback training in the experimental group, six meetings were used for the treatment, and one meeting was for post-test. The considerations of these ten meetings were to provide sufficient length of time, building constructive feedback, and measuring the effect of feedback.

The treatment of the combination of PSF on the experimental group was arranged from the steps suggested as in [2][17][22]. Particularly, the combination of PSF given in this study was the exchange papers and compare writing peer as in [17] which was elaborated in the writing process from [10] namely planning, drafting, editing (reflecting and revising), and final draft. In the experimental group, the students got a set of feedback sheets depending on the stage of the writing process. Specifically, summary of teaching scenario of the process writing approach with the combination of combination of PSF in the experimental group as well as teacher feedback in the control group is as follows.

The students were asked to write argumentative essay 1. The first stage was planning. In this stage, they were taught the argumentative essay materials. They were also asked to analyze the model text of argumentative essay. In pairs, they found a topic to write, read references, plan the essay and brainstorm ideas, do the exchange paper peer feedback, revise, organize the content of the essay, revise and were given an assignment to discuss more, collect the plan, and finish the introductory paragraph. Then, on the drafting stage, they worked in pairs to write the first draft, did the exchange paper peer feedback, revise, and finish the draft. Third, on the editing and publishing stage, the still worked in pairs to write the second draft, did the exchange paper peer feedback, revise, did the compare writing peer feedback, finish the writing, and submit it to the teacher. As the assignment, they were asked to choose a topic to write for the next meeting and read more references. Further, on the fourth meeting, the students wrote argumentative essay 2 individually. The stages were the same, yet the written feedback was different. The assisted feedback was the self-directed feedback.

In contrast, the students in the control group were asked to write two argumentative essays as well by the assistance of teacher written feedback.

In relation to instruments, two instruments were used in this study. They were English Proficiency test in the form of TOEFL-like test to classify students to get the low and higher levels and the writing test to write an argumentative essay for collecting the data in the form of the students' writing achievement. The students were asked to write an argumentative essay consisting of at least four paragraphs with the time allotment 90 minutes. The score was given based on the Content (30 score), Organization (20), Vocabulary (20), Grammar (20), and Mechanics (10). The prompt of the writing test itself was validated by an expert of writing. The things covered by the expert in validation form were the appropriateness of the test with the students' level, the length of the essays, the objective of the tests, the test instructions, and the scoring rubrics. Then, the try-out of the prompt of the writing test and the opinionnaire of the topic preference were done before the test was administered. The try-out itself was conducted to 30 English Department students of Kanjuruhan University Malang due to their similar characteristics to the subjects of this study. 
On the scoring rubric, the analytic one was used because classroom evaluation of learning was best served through an analytic one [4]. In addition, analytic scoring rubric gave high reliability and more construct validity because it was appropriate for L2 writers as there are different aspects of writing ability developed at different rates and provides useful diagnostic information [16], [28]. To see the clarity of this scoring rubric, it was tried out to three different raters. The raters were informed and trained on the use of the scoring rubric.

The data of this study were taken from the TOEFL-like test and the students' post-test scores. The first finding of this study was obtained from the TOEFL-like test. The data were scored and tabulated. These data from the TOEFL-like test were classified in the form of groups. The students in the control and the experimental groups were classified into two contrast levels namely high and low levels. Then, the second finding data were obtained from the post-test writing. In the data analysis, the first step was conducting a preliminary statistics by analyzing obtained data for fulfilling the statistical assumptions on the homogeneity and normality testing. The second step in the data analysis was testing the hypotheses by deploying Oneway ANOVA and Mann-Whitney tests using SPSS 18.0 program. Finally, the last step in the data analysis was making a decision of accepting or rejecting the null hypotheses.

\section{RESULTS AND DISCUSSION}

The results of the TOEFL-like test, the post-test, and the discussion of this study are presented in this section.

\section{A. The Results of the TOEFL-like Test}

The classification of students based on the English proficiency levels is available on Table I.

TABLE I. THE CLASSIFICATION OF THE STUDENTS BASED ON THE ENGLISH PROFICIENCY LEVELS

\begin{tabular}{|c|c|c|c|}
\hline & N & $\begin{array}{c}\text { High Proficiency } \\
\text { Level }\end{array}$ & $\begin{array}{c}\text { Low Proficiency } \\
\text { Level }\end{array}$ \\
\hline $\begin{array}{c}\text { Cont. } \\
\text { group }\end{array}$ & 31 & 15 students & 16 students \\
\hline Exp. group & 26 & 13 students & 13 students \\
\hline
\end{tabular}

Table I shows the number of low proficiency EFL students in the control and experimental groups were 29 students. The students were classified by considering their TOEFL-like test. The score range of the low proficiency students in control group was from 387 - 327 while in the experimental group was from $303-387$.

\section{B. The Results of the Hypotheses Testing}

The post-test data were computed to Kolmogorov-Smirnov and Levene's tests. The obtained results were $0.318,0.861$, $0.696,0.778,0.786$, and 0.905 indicated that all data were normally distributed. Then, the obtained results from Levene's test were $0.082,0.056$, and 0.018 indicated that two data were homogeneous and the other one was not homogeneous. Therefore, One-way ANOVA was deployed to answer research questions 1 and 2 and Mann-Whitney test was used to answer research question 3. Besides, descriptive statistics analysis was found to see the range, minimum and maximum scores, mean scores, as well as the standard deviation of the two groups as can be seen on Table II.

TABLE II. THE DESCRIPTIVE STATISTICS ANALYSIS RESULTS

\begin{tabular}{|l|l|c|c|c|c|}
\hline & N & Mean & Std. Dev. & Min & Max \\
\hline Cont. G & 16 & 62.81 & 4.38 & 57 & 71 \\
\hline Exp. G & 13 & 68.85 & 8.31 & 59 & 81 \\
\hline Cont. G (C, O) & 16 & 66.13 & 4.87 & 56 & 74 \\
\hline Exp. G (C, O) & 13 & 69.08 & 8.31 & 58 & 84 \\
\hline Cont. G (V, G, M) & 16 & 63.13 & 4.79 & 56 & 70 \\
\hline Exp. G (V, G, M) & 13 & 71.38 & 8.66 & 58 & 84 \\
\hline
\end{tabular}

The last step was testing the research hypotheses under this study. The result of One-way ANOVA and Mann-Whitney tests to evaluate the null hypotheses are seen on Table III.

TABLE III. THE RESULTS OF ONE-WAY ANOVA TEST FOR RESEARCH QUESTIONS 1 AND 2

\begin{tabular}{|c|c|c|c|c|c|}
\hline & $\begin{array}{c}\text { Sum of } \\
\text { Squa-res }\end{array}$ & Df & $\begin{array}{c}\text { Mean } \\
\text { Square }\end{array}$ & F & Sig. \\
\hline Between Groups & 261.112 & 1 & 261.112 & 6.305 & 0.018 \\
\hline Within Groups & 1118.130 & 27 & 41.412 & & \\
\hline Total & 1379.241 & 28 & & & \\
\hline Between Groups & 62.499 & 1 & 62.499 & 1.424 & 0.234 \\
\hline Within Groups & 1184.673 & 27 & 43.877 & & \\
\hline Total & 1247.172 & 28 & & & \\
\hline
\end{tabular}

TABLE IV. THE RESULTS OF MANN-WHITNEY TEST FOR RESEARCH QUESTION 3

\begin{tabular}{|c|c|}
\hline & Writing Scores \\
\hline Mann-Whitney U & 45.500 \\
\hline Wilcoxon W & 181.500 \\
\hline Z & -2.574 \\
\hline Asymp. Sig. (2-tailed) & $0.009^{\mathrm{a}}$ \\
\hline
\end{tabular}

Tables III and IV show that the obtained $p$-values were $0.018,0.234$, and 0.009 . On the first research question, it is clearly seen that the $p$-value was smaller than the level of significance $(0.018>0.05)$. There was not enough evidence to accept the null hypothesis. It was concluded that there was significant difference on the writing achievement in the students with low English proficiency level who were taught using the combination of PSF and the students with low English proficiency level who were taught teacher feedback.

In regard to the second research question, the $p$-value was greater than the level of significance $(0.234>0.05)$. There was enough evidence to accept the null hypothesis. It is noticeable that there was insignificant difference on the 
content and organization writing achievement in the students with low English proficiency level who were taught using the combination of PSF and the students with low English proficiency level who were taught teacher feedback.

Meanwhile, the third research question result shows that the $p$-value was smaller than the level of significance $(0.009>$ 0.05), meaning that there was significant difference on the vocabulary, grammar, and mechanics writing achievement in the students with low English proficiency level who were taught using the combination of PSF and the students with low English proficiency level who were taught teacher feedback.

The low proficiency EFL students in the experimental group had better writing achievement than those in the control group. The result of this study could verify the previous studies as in [29], [7], [9], and [11]. Peer and self-directed feedback successfully helped the low proficiency EFL students in the experimental group got better achievement in writing. This result was not in line with what has been discussed in [7], [24], [8], and [12] that one factor that affected this insignificant result was the English proficiency levels. This contrast result is supported by Watanabe and Swain [27] in which they found out that pattern of pair interaction plays role in the effectiveness because low proficiency students could also provide feedback to their peers.

Through the conduct of this study, further investigation to what extend the low proficiency students benefit from the combination of PSF is accomplished. The second finding of this study corroborated [3] and [13] studies that peer feedback gave limited benefits. The combination of PSF showed insignificant result on the content and organization aspects or so-called global aspects of writing. This result is in contrast to [21], [1], and [21] that peer feedback helps students to improve on the content and organization especially the feedback givers. Reference 21 focus on receiver and giver was in accordance to [27] finding that low proficiency students who acted as givers would also improved the achievement. Therefore, [6] finding is confirmed as the students with combination of PSF could not outperform those who were taught using teacher feedback in content and organization.

Subsequently, these low proficiency students were in more favor to get the teacher feedback during the writing process. Reference [14] mentioned that feedback is available when the peers are helpful in providing the input. The result that the low proficiency students had difficulties on how to respond on content and organization was because of their limited knowledge. This result implied that the low proficiency students could not work well to give feedback on content and organization for their peers as well as themselves and they were in favor to teacher feedback instead of the combination of peer and self-directed feedback. These students were then included to those who tend to choose teacher feedback [7].

Finally, the third research question result indicated that the improvement from the combination of PSF was found on vocabulary, grammar, and mechanics aspects or local aspects.
It is also in contrast to [21] and [20] that vocabulary aspect result did not get positive response. More specifically [20] also showed that grammar and mechanics got improvement than content and organization. In addition, reference [26] also shows positive results on this local aspect of writing. The availability of feedback sheets as a guidance for the low proficiency EFL students is one of the factors to this significant result. The students can review their friends' writing thoroughly by the points on the peer and self-directed feedback of this study. Previously, the students in the experimental group were also given the feedback training so that they understand how to use it well. Therefore, the feedback sheets and feedback training are two pertinent components in written feedback. Regardless low proficiency EFL students' ability in content and organization aspects, vocabulary, grammar, and mechanics aspects bring good news for teachers to implement this combination of PSF in their classroom.

However, it is unavoidable that a study is free from some unintended things. As a nature of an experimental study, every single thing under the umbrella of this study has been tried to be equal but the treatment in the control and the experimental groups. However, there might appear things which are suspicious to the researcher's eyes namely subjects of the study and length of the treatment. The number of students was one of the limitations of this study as it could not ensure the mortality threat in this study. The other limitation of this study was the length of the treatment. These six meetings used for the treatment was short compared to those longitudinal study for semesters or years. However, all limitations are expected not to affect the results of this study.

\section{CONCLUSIONS AND SUGGESTIONS}

In a nutshell, first the low proficiency EFL students who were taught using the combination of PSF had better writing achievement than the low proficiency EFL students who were taught using teacher feedback. Second, the low proficiency EFL students who were taught using the combination of PSF did not have better writing achievement than the low proficiency EFL students who were taught using teacher feedback in the aspects of content and organization. Third, the low proficiency EFL students who were taught using the combination of PSF had better writing achievement than the low proficiency EFL students who were taught using teacher feedback in the aspects of vocabulary, grammar, and mechanics. Some noticeable findings of this study are due to the significant result of the combination of PSF it is important that teacher provides wider possible range of feedback to students in writing. While teacher provides the combination of PSF in their classroom, there are encouraged to provide feedback on content and organization particularly on the low proficiency EFL students. Even though students were only successful in the vocabulary, grammar, and mechanics aspects, the combination of PSF bridges students to master the skills in giving and incorporating peer comments. 
The established conclusion above is along with the implications and suggestion for writing teachers and further researchers. This present study has established the practical and empirical evidences that peer and self-directed feedback is also beneficial for the low proficiency EFL students particularly on the vocabulary, grammar, and mechanics aspects with the availability of feedback sheets and feedback training. Therefore, it is important that writing teachers note the low proficiency EFL students content and organization aspects. In other words, writing teachers are suggested to treat certain students with appropriate feedback. Moving to the suggestions for further researchers, despite the effectiveness proof through this study, they should keep in their mind that careful consideration on the research design, timing of giving feedback which is on the process of writing instead of the product of writing, the involvement of all writing aspects, ways of giving feedback, and students differences for instance school levels need to be taken into account. Further research on moderate as well as high proficiency students and other students' differences are also interesting and fruitful cases for further researchers.

\section{REFERENCES}

[1] M. Afrasiabi, and L. Khojasteh, "The Effect of peer-feedback on EFL medical students' writing performance," Khazar Journal of Humanities and Social Sciences, 18 (4): 5 - 16. Retrieved from http://jhsskhazar.org/wp-content/uploads/2010/04/1.Laleh-Khojasteh.2-1-1.pdf, 2015.

[2] E. F. Barkley, K. P. Cross, and C. H. Major, "Collaborative Learning Techniques," San Francisco, CA: John Wiley \& Sons, 2005.

[3] M. Bijami, S. H. Kashef, M. S. Nejad, "Peer feedback in learning english writing: advantages and disadvantages," Journal of Studies in Education, 3 (4): 91 - 97. Retrieved from http://www.macrothink.org/ journal/index.php/jse/article/view/ 4314/3623, 2013.

[4] H. D. Brown, "Language Assessment: Principles And Classroom Practices, "White Plains: Pearson Education, 2004.

[5] B. Y. Cahyono and R. Amrina, "Peer feedback, self-correction, and writing proficiency of indonesian EFL students," Writing. Arab World English Journal, 7 (1): 178 -193. Retrieved from http://www.awej.org., 2016.

[6] S. K. Fordham, "Teacher and peer feedback in the ESL Composition Classroom: Appropriation, Stance, and Authorship," Electronic Dissertation. Arizona: The University of Arizona. Retrieved from http://arizona.openrepository. com/arizona/bitstream/10150/57751 8/1/azu_etd_14122_sip1_m.pdf., 2015.

[7] M. Ghani and T. Asgher, "Effects of teacher and peer feedback on students' writing at secondary level," Journal of Educational Research, 15 (2): 84 - 97. Retrieved from https://www.questia.com., 2012.

[8] D. Guenette, "Is feedback pedagogically correct? research design issues in studies of feedback on writing, " Journal of Second Language Writing, 16 (-): 40 - 53. Retrieved from http://englishunisma.com., 2007.

[9] R. Hajimohammadi and J. Mukundan, "Impact of self-correction on extrovert and introvert students in EFL writing progress," World Applied Sciences Journal, 4 (2): 161-168. Retrieved from http://www.ccsenet.org., 2011.

[10] J. Harmer, "How to teach writing," Edinburgh Gate, Essex: Pearson Education, 2004.

[11] M. Harran, "What higher education students do with teacher feedback: feedback practice implications," Southern African Linguistics and Applied Language Studies, 29 (4): 419 - 434. Retrieved from doi.org /10.2989/16073614.2011.651941, 2011.
[12] K. Hyland, "Second Language Writing," Cambridge: Cambridge University Press, 2003.

[13] W. Kangni, "Problems and Tactics in Peer Feedback in EFL Writing Teaching," 2nd International Conference on Education, Management, and Information Technology (ICEMIT 2015).

[14] S. D. Krashen, "Second Language Acquisition And Second Language Learning," Southern California: Pegamon Press, 1981.

[15] A. Landry, S. Jacobs, and G. Newton, "Effective use of peer assessment in a graduate level writing assignment: A case study," International Journal of Higher Education, 4 (1): 38 - 51. Retrieved from www.sciedu.ca/ijhe., 2015.

[16] M. A. Latief, "Scoring the quality of classroom essay," TEFLIN Journal: An EFL Journal in Indonesia, 4 (1): 94 - 112, 1991.

[17] M. Lewis, "Giving feedback in language classes," In Renandya, W. A., and Richards, J. C (Eds). RELC Portfolio Series 1, Singapore: SEAMEO Regional Language Centre, 2002.

[18] H. Liao and Y. Lo, "Peer review comments provided by high- and lowproficiency L2 learners: A comparative study," International Journal of English Linguistics, 2 (5): $45-54$. Retrieved from doi.org/10.5539/ijel.v2n5p45, 2012.

[19] M. H. Long and C. J. Doughty, "The Handbook of Language Teaching," Hoboken: Wiley and Sons, 2002.

[20] J. Lu, "Student attitudes towards peer review in university level english as a second language writing classes," Culminating Projects in English, 8 (-): 1 - 52. Retrieved from http://repository. stcloudstate.edu/cgi/ viewcontent.cgi?article $=1083 \&$ context=engl etds., 2016.

[21] K. Lundstrom and W. Baker, "To give is better than to receive: The benefits of peer review to the reviewer's own writing," Journal of Second Language Writing, 18 (-): 30 - 43. Retrieved from doi:10.1016/j.jslw.2008. 06.002, 2009.

[22] R. J. Marzano, "Classroom Assessment and Grading That Work," Alexandria: ASCD, 2006.

[23] R. S. Arslan, " Integrating feedback into prospective english language teachers' writing process via blogs and portfolios," The Turkish Online Journal of Educational Technology, 13 (1): 131 - 150. Retrieved from http://www.tojet.net/articles/v13i1/ 13112.pdf., 2014.

[24] M. Suzuki, "The compatibility of L2 learners' assessment of self-and peer revisions of writing with teachers' assessment," TESOL Quarterly, 43 (1): 137 - 148. Retrieved from http://eric.ed.gov., 2008.

[25] A. B. M. Tsui and M. Ng, "Do secondary L2 writers benefit from peer comments?" Journal of Second Language Writing, 9 (2): 147 - 170. Retrieved from http://www.fe.hku.hk., 2000.

[26] W. Wang, "How proficiency-pairing affects students' peer-mediated revisions of EFL writing: Three case studies," Canadian Center of Science Education, 8 (5): 22 - 32. Retrieved from http://files.eric.ed.gov/fulltext/EJ1075254.pdf., 2015.

[27] Y. Watanabe and M. Swain, "Effects of proficiency differences and patterns of pair interaction on second language learning: collaborative dialogue between adult ESL learners," Language Teaching Research, 11 (2): 121-142. Retrieved from http://10.1177/136216880607074599, 2007.

[28] S. C. Weigle, “Assessing Writing," Cambridge: Cambridge University Press, 2002.

[29] J. White, B. Morgan, and B. Fuisting, "Peer review in EFL writing: teacher attitudes," TESOL Arabia Perspectives, 22 (2): 20 - 27. Retrieved from www.tesolarabia.org., 2014.

[30] S. Yu, "An exploratory study on the role of L1 use in peer written feedback of L2 writing," Porta Linguarum, 25 (-): 135 - 146. Retrieved from http://www.ugr.es/ portalin/articulos/PL_numero25/10\%20Shulin. pdf., 2016. 